\title{
Review on Milk Yield, Composition, Quality and Microbial Contamination Dairy Cattle Milk in Ethiopia
}

\author{
Bamlaku Getie \\ Woreta ATVET College \\ Yibeltal Aynalem \\ Woldia university
}

\begin{abstract}
Ethiopian milk production depends on mainly indigenous livestock genetic resources dominated by small holder farmers. The estimated numbers of indigenous milking cows in Ethiopia is about nine million and are in the hands of smallholder farmers and pastoralists under traditional contributions of the sector to the country's gross domestic product and exports. Milk and milk products play an important role in human nutrition throughout the world. Milk is also highly perishable and can easily be adulterated whilst the quality of the milk is highly dependent on farm management. Sources of microbial contamination of milk like milking environment, cows udder, milker, milking equipments and water the most dominant factor for the quality of milk. To prevent or retard growth of bacteria in milk and to maintain its quality for domestic consumption or transportation to the processing plant cooling, boiling and pasteurization are important to control measures of microbial contamination in raw milk. Clot on boiling test is performed by boiling a small amount of milk in a spoon, test tube or any other suitable container. Chemical composition, particularly milk fat content is used as quality test. The solid constituents of milk make an important food item from both nutritional as well as processing point of view.
\end{abstract}

Keywords:- contamination, composition handling, milk quality

DOI: $10.7176 / \mathrm{JBAH} / 10-19-02$

Publication date:October $31^{\text {st }} 2020$

\section{INTRODUCTION}

Livestock production contributes $30-35 \%$ of the GDP and more than $85 \%$ of farm cash income. In this respect, milk production is playing a vital role in the livelihoods of the people of Ethiopia. This sub-sector also accounts for $19 \%$ of the export earnings (CSA, 2016). This livestock sector has been contributing considerable portion to the economy of the country, and still promising to rally round the economic development of the country. It holds latent quality for livestock products. Traditional milk production accounts for $98 \%$ of the milk production in the country Yonad (2009). Small holder activity especially on dairy sector can contribute importantly to poverty reduction and nutrition demands of the country Ahmed Mohammed et. al, (2004).

The characteristics of milk is deteriorated by various causes and includes; environmental and poor management practices, therefore a decrease in the quality of up to 20-35\% have been reported in Ethiopia for milk and dairy products from milking to consumption (Getachew Felek,2003). Poor handling of traditional milk and milk products during the processing activities account for a loss of about $40 \%$ in terms of quality and quantity (CSA, 2010).

Milk is the most popular food for human consumption and contains numerous nutrients such as water, fat, protein, lactose, minerals and vitamins (Walstra et al., 2006). It is the major source of regular income for Smallholder milk producers because it is produced and sold daily (Dugdill et al, 2013). Besides its benefit, it is serves as an excellent growth medium for a wide range of microorganisms (Walstra et al., 2006). Bacterial contamination of raw milk can be originated from three main sources; within the udder, exterior to the udder and from the surface of milking materials, milk handling and storage equipments. Similarly, the surrounding air, feed, soil, feces and grass are also possible sources of contamination (Torkar and Teger, 2008).

In Ethiopia milk produced at smallholder farm is marketed without quality control measures. Hygienic control of milk and milk products is not usually conducted on routine bases. Apart from this, door-to-door raw milk delivery in the urban and peri-urban areas is commonly practiced with virtually no quality control at all levels (Godefay and Molla, 2000). Although, properly operational formal marketing and grading system targeted towards relating quality of products to market price is not well established, provision of milk and milk products of good hygienic quality is desirable from consumer's health point of view (Zelalem, 2012).

On the other hand, the Chemical composition, particularly milk fat content is used as quality test (Zelalem, 2010). The nutritional as well as the economic value of milk is directly associated with its solids content. The higher the solids content better its nutritional value and more of a milk product can be made. Protein content being one of main quality determining criteria applied to milk payment to producers in many countries where others are priced according to fat and solids-non-fat composition (FAO, 2004).Information on the microbial and chemical composition of milk was essential to understand the quality of marketed milk supply. Previous research works 
mainly focused on microbial quality of fluid milk and very few studies were reported in both microbial and chemical composition at smallholder milk producer and dairy cooperatives. Objective, To review milk yield, composition, and quality of lactating cows.

\section{LITERATURE REVIEW}

\section{Milk Production in Ethiopia}

Ethiopia possesses the largest livestock population in Africa. Recent estimates indicated that the country have about 50.9 million heads of cattle, 24.06 million goats, 25.5 million sheep and 2.3 million camels (CSA, 2010). Milk production system can be categorized based on agro-ecology, socio-economic structures of the population and type of breed and species used for milk production can be classified into two major systems, namely rural dairy system (pastoralists, agro-pastoralists, and mixed crop-livestock producers) and urban and peri-urban dairy systems (Getachew and Gashaw, 2001). Milk production depends on mainly indigenous livestock genetic resources dominated by small holder farmers specifically on cattle, goats and camels. The indigenous breeds accounted for 99.19 percent, while the hybrids and pure exotic breeds were represented by 0.72 and 0.09 percent, respectively (Zelalem et al., 2011).

Milking cows in the traditional sector have an average lactation length of 190 days and an average milk yield 1.9 liters per day excluding the calf has suckled (MOA, 2005). The total annual national milk production in Ethiopia received from 9.6 million dairy cows and the product is estimated to be 2.9 billion liters which is, 1.69 liters yield per cow per day on average (FAO, 2010).

\section{Productivity of Dairy Cattle}

The estimated numbers of indigenous milking cows in Ethiopia is about nine million and are in the hands of smallholder farmers and pastoralists under traditional contributions of the sector to the country's gross domestic product (GDP) and exports are about 60 and 90\%, respectively. In Ethiopia about 300,000 crossbred or upgraded cows are used for milk production under relatively improved management conditions in urban and peri-urban areas. The total milk production from about 11.3 million milking cows is estimated at about 3.2 billion liters, an average of 1.54 liters/cow per day over a lactation period of about 6 months (CSA, 2016). Gebre kidan Tesfay (2010) reported that, the average daily milk yield of the indigenous local dairy cattle in central zone of Tigray was 2.56liters.In northern Amhara. The report indicated that the daily milk yield of indigenous local cattle breed differ with lactation length ,management, nutrition genetics of the sample population and parity. The daily milk yield of Fogera, Dembia and Wogera cattle in the first lactation were; 2.23, 1.8and 1.46liters respectively (Zewdu Wuletaw, 2004).

In the past, most of the interventions to develop the dairy sector focused more on increasing production, especially in the so-called high potential areas and with less attention to input supply and marketing systems and government engagements focused on input supply oriented services aimed at tackling problems of restricting increases in milk production, with little attention to the development of appropriate milk marketing and processing systems. In general, the development of improved marketing system is pivotal to increase production (Tsehay Redda, 2002). Most of the interviewed small scale dairy producers in the study area produce on average 10.5 and 2.6 liters of milk/ day/ cow from cross breed and local cow respectively (Girma Debele and Verschuur, 2014) Productivity of the dairy herd is low with average milk yield of 1.3liters -1.54 liters/day for an average lactation period of 180-210 days. Cross-bred cattle have a higher level of production estimated at an average of 10 liter/head/day (EDDP) (Dairy Value Chains, 2010). According to Girma Debele and Verschuur (2014) findings revealed that average lactation length of cross breed and local cows in the study area to be 240 and 255 days respectively. Because of this fact some of dairy farmers reported that they have milked their cow even during the whole pregnancy period.

On average, crossbreed cows produces 8 liters per day per cow and the indigenous one produces 2 liters per day per cow ( Zewdu Wuletaw, 2004; Adebabay Kebede, 2009). Another study conducted in North Showa zone indicated that $50 \%$ crossbreeds produced more amount of milk (1511.5liters) than local breeds (457.89liters) per lactation Belay Duguma et al, (2012). Mulugeta Ayalew and Belayneh Asefa (2013) reported that, mean milk production per lactation between Horro and Holstein Friesian was 2333.63 L. This could be due to complementary effect to the achievable environment. A number of production constraints are seriously affecting smallholder dairy production.

In addition to already highlighted lack of capital to acquire the crossbreeds, many farmers face difficulties in getting full information on the breeds they are going to buy. Other factor hampering milk production include inadequate feed base, high cost of bought-in feeds, shortage of cash to buy concentrate feeds (Zewdu Wuletaw, 2004; Belete Anteneh, 2006 ). Milk yield performance of cows as reported by farmers varies across the different dairy production systems in the study area, mainly due to differences in breed and management (Azage Tegegne et al., 2013). 


\section{Milk Handling}

Milk and milk products play an important role in human nutrition throughout the world. Milk is also highly perishable and can easily be adulterated whilst the quality of the milk is highly dependent on farm management. Strict and comprehensive dairy regulations are therefore customary and necessary Banda (2010), the safety of dairy products with respect to food borne diseases is a great concern around the world. This is especially true in developing countries where production of milk and various dairy products take place under rather 9 unsanitary conditions and poor production practices. Equipment used for milking, processing and storage determine the quality of milk and milk products. The use of plastic and traditional containers can be a potential source for the contamination of milk by bacteria, because this allows the multiplication of bacteria on milk to contact surfaces during the interval between milking (Abebe Berada et al.,2012 ).

\section{Sources of Microbial Contamination of Milk}

The common predisposing factors of milk contamination by microorganisms are milking environment, cows, milking personnel, milking equipments, and water (Mbabazi, 2005).

\section{Milking environment}

Maintaining the sanitary condition of the milking area is important for the production of good quality milk (Zelalem, 2010). Dirty milking places tend to breed flies, which may fall in causing milk contamination and thus spoilage may occur (Mbabazi, 2005). When a cow urinates or defecates in the course of milking some of its urine or dung particles may drop into the milk (Mbabazi, 2005).

\section{Cow (Udder)}

Cleaning the udder of cows before milking is one of the most important hygienic practices required to ensure clean milk production (Zelalem, 2010). This is an important activity since the udder of the milking cows could have direct contact with the ground, urine, dung and feed refusals. Cleaning and removing of soil particles, bedding material and manure from the udder and flanks is necessary to prevent the entry of many types of bacteria into the milk (O’Connor, 1995). Udder washing with clean water and drying using hand towels reduces milk contamination by transient bacteria located on the udder (Robert, 1996). Special care must be given to the cloths used for cleaning the udder. The re-use of cloths for cleaning and sanitizing may result in re-contamination of the udder. It is therefore recommended that separate cloths be used for cleaning and sanitizing and, if possible, each cloth should be used for one cow only (O'Connor, 1995). Not washing the udder before milking can impart possible contaminants into the milk. A maximum reduction of teat contamination of $90 \%$ can be achieved with good udder preparation before milking. This depends on the initial level of contamination and the way of udder preparation. So with high initial contamination levels this $90 \%$ reduction might not be reached (Murphy, 1996).

\section{Milker}

Milk handling personnel (milker) may contribute various organisms including pathogens especially when they are careless, uninformed, or willfully negligent, directly to milk (Ashenafi, 1994). Organisms may drop from hands, clothing, nose, and mouth and from sneezing and coughing. It is important for milk men to be in good health so that they can be a source of infectious diseases such as tuberculosis.

\section{Milking equipments}

Poorly cleaned and sanitized milking utensils may be the source of many microorganisms. Milk drops left on the surface of milking equipments act as excellent media for the growth of a variety of bacteria. Milk equipment is not properly cleaned and sanitized after use. Milk residues left on equipment and utensil surfaces provide nutrients to support the growth of many microorganisms, including pathogens . In case cracked milking equipments large number of bacteria enter and grow in the cracks, are difficult to clean. The bacterial load of milk increases during transportation and if the transportation equipment is not appropriate the bacterial counts increase causing spoilage before milk reaches its destination (Grillet et al., 2007). Milking equipment should be easy to clean. Aluminum and stainless steel equipment are mostly preferred (Zelalem, 2010).

\section{Water}

Water serves as primary sources of microorganism's contamination (Mbabazi, 2005). If Water is obtained from an open water supply care should be taken to prevent drainage that may contain human feces and other contaminants gaining entry into the source .

\section{Control Measures of Microbial Contamination in Raw Milk Cooling:}

To prevent or retard growth of bacteria in milk and to maintain its quality for domestic consumption or 
transportation to the processing plant, it is essential to cool fresh milk as quickly as possible (O'Connor, 1995). Prompt cooling or chilling of milk at a temperature of $5^{\circ} \mathrm{C}$ or below is necessary to minimize microbial growth and prevent milk quality deterioration during handling, storing and transporting before processing of the raw milk.

In order to facilitate bulking of raw milk supply and transport the incoming milk, refrigeration facilities are provided at points of collection and transport means to maintain the temperature as much as possible (Getachew et al., 2008). In the tropical countries of Africa with high ambient temperatures, lack of refrigeration facilities at the farm and household level imply that raw milk will acidify very fast (Godefay and Molla, 2000). Therefore the collection systems must be designed to move the milk to the cooling and/or processing center in shortest possible time. In addition every effort should be made to use available systems such as water= cooling, air circulation or shaded areas to reduce milk temperature.

\section{Boiling:}

It is the easiest and most practicable method of making milk safe in every home. As soon as raw milk is produced or delivered, it should be boiled. Boiling involves raising the temperature to the boiling point and maintaining at this temperature for a few minutes. Then the milk should be cooled immediately. The temperature should be maintained below $10^{\circ} \mathrm{c}$. Since this may be impracticable at home, preferably the milk must be consumed as soon as possible after cooling and not an extended period of time after it has been boiled and cooled (Gebra-Emanuel, 1997).

\section{Pasteurization:}

It is the main safeguard against pathogenic organisms in milk. The combination of pasteurization, care in production and processing, and improved storage has resulted in relatively safe milk supply. Milk borne diseases like tuberculosis, diphtheria, and scarlet fever have been practically eradicated. Also, the shelf-life of milk has been increased from a few days to a few weeks (Vasavaoa and Smith, 1987).

\section{Microbial Tests of Raw Milk}

Clot on boiling test: This is one of the oldest tests for abnormal acidity levels in milk, which is brought about by too much acid in milk $(\mathrm{pH}<5.8)$. The test is performed by boiling a small amount of milk in a spoon, test tube or any other suitable container. If there is coagulation or precipitation, the milk fails the test. The test is not sensitive to slightly sour milk (O'Connor,1995; Draaiyer et al, 2009). Alcohol test:-The test is quick, simple and is used as a screening test. It is based on instability of the proteins when the levels of acid and/or rennet are increased and acted upon by the alcohol. Also increased levels of albumen (colostrum milk) and salt concentrates (mastitis) results in a positive test. The test is done by mixing equal amounts of milk and $68 \%$ ethanol (usually $2 \mathrm{ml}$ ) in a small bottle or test tube. If the tested milk is of good quality, there will be no coagulation, clotting or precipitation upon shaking (O'Connor, 1995, Draaiyer et al, 2009).

The alcohol test can detect milk whose $\mathrm{pH}$ is 6.4 or lower and is more sensitive than the clot on-boiling test, which only detects milk pH levels of 5.8 and below. Colostrums and mastitis milk may give a positive alcohol test Standard plate count: The standard plate count is generally accepted as the most accurate and informative method of testing bacteriological quality of milk (Godefay and Molla, 2000). The total plate count of microbes in milk provides useful general information on the microbiological quality of milk. Total or aerobic plate count shows only the mesophillic aerobic organisms as incubation is done under normal atmospheric conditions at $35^{\circ} \mathrm{C}$ for 48 hours. The number of bacteria in aseptically drawn milk varies from animal to animal and even from different breasts of the same animal. On average, aseptically drawn milk from healthy udders contains between 500 and 1000 bacteria $\mathrm{ml} / \mathrm{l}$.

\section{Chemical Composition of Milk}

Chemical composition, particularly milk fat content is used as quality test. The solid constituents of milk make an important food item from both nutritional as well as processing point of view. Milk fat and protein are most important components of different varieties of most shelf stable milk products. It is therefore very important to determine the major chemical compositions of milk as it is the basis of further processing into more shelf stable products.

Moreover, knowledge of the total solids and solids-not-fat (SNF) content of milk is necessary when it is sold for liquid consumption. In most countries, milk which is offered for sale and for consumption must conform to certain legal standards with regard to its total solid contents, for example the minimum $3 \%$ fat and $8.5 \%$ solids contents -not-fat. The yield of dairy products obtained from milk will depend on the amount of constituents (total solids) present. The greater the amount of fat and protein in milk the greater the yield of cheese and milk with a high fat content gives more butter than milk with a lower fat content (O'Connor, 1995) Normal cow's milk contains approximately $87.4 \%$ water and $12.6 \%$ milk solids (Goff, 2010). The solids consists of comprises $3.9 \%$ fat, $3.2 \%$ protein, $4.6 \%$ lactose and $0.9 \%$ others like minerals and vitamins (FAO, 1986). The composition of milk 
is affected by a number of factors including genetic and environmental factors (O'Connor, 1995). The factors responsible for variations in milk composition include breed and individuality of the cow, interval between milking, stage of lactation, age and health status of the cow, feeding regime and completeness of milking (O'Connor, 1995).

The natural composition and Physico-chemical properties of raw milk may change by Adulteration of milk by intentional addition of water or other substances are a common problem in many developing countries. Adulteration is illegal because it alters the natural composition of milk and can introduce harmful bacteria and other dangerous substances into milk. Water adulteration lowers the specific gravity and increases the freezing point of milk. The Normal whole milk specific gravity ranges 1.026 to 1.032 milk collection centers and processors routinely determine the specific gravity of raw milk and reject milk suspected of having been adulterated (Kurwijila, 2006).

\section{RECOMMENDATION}

* The management and husbandry practice of dairy cow should be improve to increase the milk yield.

* Genetic potential improvement in Ethiopia is crucial for sustainable development and food security.

* Post harvest handling and processing of milk and milk products determine composition, quality and contamination of row milk and the government and nongovernmental organizations should focus on these.

\section{REFERENCES}

Abebe Bereda, Zelalem Yilma and Ajebu Nurfeta. 2012. Hygienic and microbial quality of raw whole cow's milk produced in Ezha district of the Gurage zone, Southern Ethiopia. Wudpecker Journal of Agricultural Research $1(11): 459-465$

Adebabay Kebede. 2009. Characterization of milk production Systems, Marketing and OnFarm Evaluation of the Effect of Feed Supplementation on Milk Yield and Milk Composition of Cows at Bure District, Ethiopia A Thesis Submitted to the Department of Animal Science and Technology School of Graduate Studies. Bahir Dar University Bhair Dar Ethiopia.

Alehegne Wubet, 2004. Bacteriological quality of Bovine milk in small holder dairy farms in Debre zeit, Ethiopia M.Sc Thesis Addis Ababa University, Ethiopia

Alganesh Tola. 2002. Traditional milk and milk products handling practices and raw milk quality in Eastern Wollega. M.Sc. Thesis, Alemaya University. Dire Dawa, Ethiopia.

Ashenafi Mengstu. 1994. Microbial load, microflora, and keeping quality of raw and pasteurized milk from a dairy farm. Bulletin Animal Health Production Africa, 42: 55-59

CSA (Central Statistics Authority). 2010. Agricultural sample survey. Report on crop and livestock product utilization. The Federal Democratic Republic of Ethiopia, Central Statistical Agency (CSA). Private Peasant Holdings. Statistical Bulletin 468, Addis Ababa, Ethiopia

Draaiyer, J., Dugdill, B., Bennett, A. and Mounsey, J. 2009. Milk testing and payment systems resource book; a practical guide to assist milk producer groups. Food and Agriculture Organization (FAO).

Dugdill, B., Bennett, A., Phelan, J. and Bruce, A. 2013. Dairy industry development programs their role in food and nutrition security and poverty reduction. 42

FAO (Food and Agricultural Organization ). 1986. Manuals of food quality control, food analysis, quality adulteration and tests of identity, Food and Nutrition paper and Agricultural Organization of the United Nations, Rome.

FAO (Food and Agricultural Organization) 2004 Milk producer group resource book: apracticalguidetoassistmilkproducergroups,byJurjenDraaijer.Rome.Availableathttp://www.karmay.org/redir ect/strred.asp?docId=21604. Accessed 21 January 2015.

FAO (Food and Agriculture Organization). 2010. Status and prospects for smallholder milk production: A global perspective, by T. Hemme and J. Otte. Rome.

Gebra-Emanuael Teka 1997. Food Hygiene principles and methods of food borne disease.

Girma Debele and Verschuur,M. 2014. Analysis of milk value chain: the case of Ada'a dairy cooperative in Ada'a district, East Shawa zone of Oromia regional state, Ethiopia. Wudpecker Journal of Agricultural Research 3(1), pp. $016-025$

Getachew Felleke and Gashaw Geda. 2001. The Ethiopian Dairy development Policy options, Ministry of Agriculture and Food and Agriculture Organization, Addis Ababa, Ethiopia.

Getachew Felleke. 2003. Milk and dairy products, post-harvest losses and food safety in Sub Saharan Africa and the Near East. A review of the Small Scale Dairy Sector Ethiopia. FAO Prevention of Food Losses Programme. FAO, Rome, Italy.

Godefay Bekele and Molla Bayileyegn. 2000. Bacteriological quality of raw milk from four dairy farms and milk collection center in and around Addis Ababa. Berl. Münch. Tierärztl.Wschr. pp 113.

Godfery.K, 2013. Milk Quality and On-Farm Factors Leading To Milk Spoilage in Bugaaki Sub County- Kyenjojo District. Uganda, M.Sc Thesis Makerer University, Uganda. Goff, H.D. 2010. Introduction to dairy science 
and technology: Milk history, consumption, production, and composition. Dairy science and technology. University of Guelph. (www.foodsci.uoguelph.caldairyedulitro.html, Reviewed on 16/2/2015)

Grillet N., Grimaud P., Sserunjogi M.L. 2007. African Journal of Food, Agriculture, Nutrition and Development, Issue 16 (7), auteurs de cette publication.

Haile Welearegay, Zelalem Yilma, Yosef Tekle. 2012. Hygienic practices and microbiological quality of raw milk Produced under different farm size in Hawassa, Southern Ethiopia. Journal of Agricultural Research, 1(4): 132- 142. 44

LIVES (Livestock and Irrigation Value Chain for Ethiopian Small holders). 2012 Zonal diagnosis and intervention plan in West Shoa Zone Oromia Region Ethiopia.

Mbabazi. P. 2005. Milk industry in Uganda, 1st Edition, Fountain Publishers Kampala, pp 27- 52.

McDonald P, Edwards RA, Greenhalgh JFD, Morgan CA, 1995. AnimalNutrition. $5^{\text {th }}$ edition. Longman Scientific and Technical. Copublishedin the United States with John wiley and Sons, Inc., NewYork, 607 pp.

MoARD (Minister of Agricultural Rural Development). 2005. Agricultural marketing strategy, Addis Ababa, Ethiopia.

Mohammed, A.M. Ehui.S and Yemeserach Assefa. 2004. Dairy Development in Ethiopia. EPTD Discussion International Food Policy Research Institute, NW Washington, D.C. Paper No.123.

O’Connor, C.B. 1995. Rural Dairy Technology. ILRI Training Manual No.1. International Livestock Research Institute (ILRI), Addis Ababa,Ethiopia.

Rahel Nebiyu. 2008. Traditional and improved milk and milk products handling practices and compositional and microbial quality of raw milk and butter in Delbo, Water shed of Wollayta Zone. MSc Thesis, Hawassa University, Hawassa, Ethiopia.

Ruegg, P.L. 2003. Practical food safety interventions for Dairy Production. Journal of Dairy Science, 86: 1-9.

Sanderson, M.W., Sargeant, J.M., Renter, D.G., Griffin, D.D. and Smith, R.A. 2005. Factors associated with the presence of coli forms in the feed and water of feedlot cattle. Applied Environmental Microbiology, 71: 60266032.

Sintayehu Yigerem, Fekadu Beyene, Azage Tegegne and Berhanu Gebremedhin. 2008. Dairy production, processing and marketing systems of Shashemene-Dilla area, South Ethiopia.

SNV (Netherlands Development Organization). 2008. Dairy Investment Opportunities in Ethiopia. by TAM Consult, Netherlands Development Organization (SNV), Addis Ababa, Ethiopia. pp59.

Solomon Mosu, Mulisa Megersa, Yibeltal Muhi, Desalegn Gebremedihn and Simenew Keskes. 2013. Bacteriological quality of bovine raw milk at selected dairy farms in Debre Zeit town, Ethiopia. Comprehensive Journal of Food Sciences and Technology Research, 1(1): $1-8$.

Torkar, K.G. and Teger, S.G. 2008. The microbiological of raw milk after introducing to the two day's milk collecting system. Acta Agri. Slove., 92(1): 61-74.

Valk, van der O, Tessama A. 2010. The formal dairychain of Addis Ababa, an analysis of the integration ofsmall -scale dairy farmers in Ethiopian, Addis Ababa Vasavaoa, P.C. and Smith D.E. 1987. Symposium: Health related aspects of milk and Milk products: an introduction. Journal of dairy science, 70: 381-382.

Walstra, P., Wouters Jan, T.M. and Geurts, T.J. 2006. Dairy Science and Technology Second Edition. CRC Press Taylor and Francis Group. pp 763.

Younan, M., Zakaria, F., Matthias, M. and Ragge, D. 2007. Camel dairy in Somalia limiting factors and development potential.CH-8092 Zurich, Switzerland, (www.sciencedirect.com, Reviewed on 27/12/11).

Zelalem Yilma and Faye B. 2006 Handling and microbial load of cow's milk and irgofermented milk collected from different shops and producers in central highlands of Ethiopia. Ethiopian Journal of Animal Production, 6(2): 67-82

Zelalem Yilma, Emmannuelle Guernebleich and Ameha Sebsibe. 2011. A review of the Ethiopian Dairy Sector, FAO Sub Regional Office for Eastern Africa (FAO/SFE).

Zelalem Yilma. 2010. Quality factors that affect Ethiopian milk business: Experiences from selected dairy potential areas. Netherlands Development Organization, Addis Ababa,Ethiopia

Zelalem Yilma.2012. Microbial properties of Ethiopian marketed milk and milk products and associated critical points of contamination: An epidemiological perspective, epidemiology insights, Dr. Maria De Lourdes Ribeiro De Souza Da Cunha (Ed.), ISBN: 978-953-51-0565-7 